Proceedings of the 2018 International Scientific Conference 'Economic Sciences for Agribusiness and Rural Economy' No 1, Warsaw, 7-8 June 2018, pp. 389-395

ISBN 978-83-7583-802-2

DOI: 10.22630/ESARE.2018.1.55

\title{
BEHAVIOURAL FINANCE IN AGRIBUSINESS - THE BIRTH OF A CONCEPT
}

\author{
Tomasz Pawlonka, $\mathrm{PhD}^{1}$
}

Faculty of Economic Sciences, Warsaw University of Life Sciences - SGGW

\begin{abstract}
Up until now, a model approach has constituted the core of mainstream economics with regard to the decision maker and decision-making conditions. The financial (and economic) crises appearing with increased frequency and numerous market anomalies, although considered predictable by economists and being only a residual component of econometric models, are related to the growing financialization of the economy and an existing asymmetry of information in the absence of full decision-maker rationality. The importance of the psychological characteristics of individuals, their knowledge, the level of trust and priorities, recognized more and more commonly in economic practice, make it necessary to conduct research to identify 'difficult quantifiable' characteristics of decision-makers, including their purely economic considerations. (as a supplement to previous economic considerations, including the inclusion of new variables to econometric models that have been in operation for years). The aim of the study was to systematize the evolution of the homo oeconomicus concept along with an indication of further possible directions in its development. A survey of behavioural finance in relation to agribusiness has also been reviewed, which is a perfect example of the evolution of mainstream economics.
\end{abstract}

Keywords: homo oeconomicus, rationality, agriculture, speculative motif JEL codes: G41, Q14, D87

\section{INTRODUCTION}

Issues concerning the way people make decisions in the sphere of economic life attract the interest of researchers from many scientific areas related to economics - sociology, psychology, philosophy, ethics and others. Knowing the motives of an individual's actions is the basis for explaining and predicting behaviour in specific situations and in specific conditions. The first concepts that capture the communality of human life appeared in antiquity. The dilemma concerning human nature, its weaknesses and shortcom- ings, was already present at the stage of the collective community in the Platonic approach (Plato, 2003) and the Aristotelian 'political animal' (Aristotle, 1953). The tearing desires of human nature, according to Hobbes (1954), are the result of extreme selfishness of every person, lack of morality and susceptibility to breaking the rules of law that lead to 'bellum omnium contra omnes' (war of all with everyone). According to Adam Smith (1954, 1989), although man follows the implementation of his own selfish plans and ambitions to achieve them, he is willing to pursue the interests of strangers, provided that they have a

${ }^{1}$ Corresponding author: Nowoursynowska 166, 02-787 Warsaw, Poland, tomasz pawlonka@sggw.pl, +48 505917778 
beneficial effect on achieving their own goals. This idea, derived from the philosophical concept of economic harmonization of human nature of John Locke (1995), laid the foundations for the concept of homo oeconomicus.

\section{MATERIALS AND METHODS}

The model view of mainstream economics requires the adoption of clear rules for decision-makers, who, while choosing between different variants of action, should be characterized by a set of certain personality traits, full knowledge and full rationality, so that the decision made by them in the conditions of an effective market, without asymmetry of information, represent the best option from the point of view of their Bayesian goals (Wilkinson and Klaes, 2012). The adoption of specific, time-constant assumptions about the characteristics of each decision maker, including their goals and expectations allows the economy to model variables such as supply, demand, price and others. This assumption, being a somewhat simplified model of the decision maker, although useful from the point of view of econometric modelling, is becoming increasingly distant to reality, as evidenced by the past financial crisis (crisis of trust) and daily economic practice.

Although the awareness of the lack of full rationality of the decision-maker has been functioning in economics for hundreds of years, the bases of contemporary behavioural finances, including the condition of limited rationality and psychological analysis, have somewhat sporadically appeared since the middle of the last century. However, the methodological workshop and the achievements of behavioural finance should still be considered insufficient.

The aim of this study is to systematize the evolutionary approach to the concept of homo oeconomicus, along with an indication of further directions to its development. In order to achieve the main goal, a review of research in the field of behavioural finance with regard to the finances of agriculture (agribusiness) was carried out. Through the evolution of the views of mainstream economics they are inherently coupled with the development of behavioural finance. The article is descriptive and based on a re- view of the history of economic thought and a review of global research in the field of behavioural finance in agribusiness.

\section{EVOLUTION OF HOMO OECONOMICUS IN ECONOMIC THEORY}

In the 1960s, John Stuart Mill (1959) stated that economics is by definition a science of selfish behaviour, because every person cares about their own interests. This utilitarian philosophy defined 'own interests' as an achievement of happiness, which is the only goal and good to which all people aspire. Humans are absorbed, therefore, by the main purpose of their existence and subordinate all actions to this goal. The anthropological and ethical concept of human nature described by Wilhelm von Humboldt (2008) is therefore the quintessence of homo oeconomicus - greedy, characterised by a high level of individualism and possessing all rationality. Such a person, acting rationally, maximizing usability and always choosing the best variants of action has for years constituted the foundation for the classical idea of profit maximization.

Herbert Simon (1976) writes that according to the theory of limited rationality, humans have a limited ability to acquire and process information and analyse its consequences, therefore the decisions made by them are based only on some alternative options, with a fairly limited spectrum of capabilities. Also Harveey Leibenstein (1988) postulates the inclusion of social and psychological factors in the classic concept of homo oeconomicus - mainly selective rationality. This concept assumes the inclusion of realism in assessing the situation, calculating the benefits and counting the limitations related to personality traits, independence of judgment, reflexes, and sensitivity. According to Becker (1990), the concept of homo oeconomicus should take into account the lack of full rationality, as well as transaction costs and risk issues. In the contemporary canon of finances, an economic man should be replaced by a man looking for satisfactory solutions (March and Simon, 1964; Augier and Feigenbaum, 2003). Research on the economic behaviour of people, its decisions and destinations should include elements of sociological, psychological and ethical sciences. As Simon notes, rationality 
requires full knowledge and the possibility of predicting the consequences of any considered choices. Knowledge of possible choices is incomplete and in practice the entrepreneur takes into account only some variants - not all options can be considered. The mere assessment of the entrepreneur's choices is the result of supporting the inadequate experience reinforced by the imagination and individual preferences of the decision maker, which makes those choices only aspire to be optimal, although they do not have to be (Simon, 1976). The reasons for limited rationality should be found in insufficient information and in its asymmetry, but also in the lack of time and money (information is not free), in the lack of the ability to remember all variables, or, as Stoner, Freeman and Gilbert (1999) note - in the limits of the decision maker's intelligence. Significant distortions in complete information are also the result of individual needs, motives and aspirations, but also unconscious habits, habits of reflexes, as well as the individual's values and tasks that diverge from the organization's fundamental goals (March, Simon, 1964). As a result, the structure of the choices made by entrepreneurs resembles the mechanism of 'stimulus - reaction' rather than the model of rational choice between the known alternatives. Rationality places itself therefore within the psychological environment or, more broadly, through the prism of a dynamically changing environment. The adopted model of incomplete rationality therefore presents the choice of a specific solution as a result of a conscious level of aspiration, which additionally changes over time depending on the circumstances, experiences or emerging alternatives (Simon, 1979). As Leibenstein (1988) notes, the homo oeconomicus model should not be completely ruled out, because rational economic reasons have not lost their validity due to the perception and inclusion of human imperfections in research. A situation in which a person behaves rationally is, however, extremely rare, or even theoretical and utopian.

The necessity to supplement the neoclassical homo oeconomicus paradigm with the assumption of incomplete rationality is perceived by contemporary economics, as evidenced by the awards granted by the Bank of Sweden, to researchers such as Kahneman, Tversky and Thaler. As Thaler and Sunstein (2012) points out, behavioural economics is too delicate to deal with neoclassical models, trying only subtly to indicate the deviations appearing from them, not to say that these models are incorrect. According to Mullainathan and Thaler (2000), further economic researches should take into account three basic assumptions functioning in the classical economy: unlimited rationality, lack of weak will and lack of altruism.

\section{THE BEHAVIOURAL ASPECTS OF MAINTAINING CASH}

Beginning with the analysis of consumption as an aggregate quantity characterizing all individuals in society, Keynes created a theory of consumption including psychological and social factors in the decision-making process, such as an extreme propensity for consumption and saving. He also drew attention to the influence on the economic decisions made by entities which are related to the conditions in which they operate, with their knowledge, the accuracy of their predictions and trust in the economy (or state institutions). As a result, economic operators, according to Keynes (2003), make decisions in conditions of limited rationality and very often are characterized by a so-called animal nature. This specific irrationality, a bandwagon effect and a series of emotional behaviours also refer to the motives of keeping cash. Transactional, prudential and speculative motives related to maintaining liquid funds are a combination of rational, economic and effective determinants as well as a number of psychological factors based on individualized expectations, emotions and subjective judgements. The transaction motive constitutes a rational premise for maintaining financial liquidity related to the necessity of current and future expenditures. The precautionary theme contains in its design an element of rationality, because it constitutes a necessary safety margin related to uncertainty regarding future inflows and outflows. This motive to a large extent refers to psychological aspects related to the management of funds. It refers, i.a. to psychological aspects related to risk appetite / tolerance, predictions based on incomplete information, or a preference for liquidity. The speculative motif is connected with the need to have cash in order to use potential future mar- 
ket opportunities. Similarly to the previous motives, it has fully rational premises related to the willingness to implement profitable investment projects in the future. In reality, however, it is based on expectations, postponing consumption over time and the lack of knowledge of possible variants of the future situation and their consequences.

As Franc-Dąbrowska (2011) points out, the identification of cash maintenance motifs in agriculture enterprises is an extremely important area of research due to the unity of the households and the farms. These farms are characterized by very low indebtedness and a conservative approach to managing financial liquidity. As Franc-Dąbrowska (2008) and Mądra (2007) points out, in relation to the Keynesian approach to maintaining financial liquidity, agricultural enterprises are dominated by the prudent motive of keeping cash. Simultaneously, the speculative motive is virtually unnoticeable. This approach indicates behavioural aspects related to financial liquidity management - primarily with respect to risk aversion, which is illustrated by the shape of a value curve for profits and losses in the first part of perspective theory in terms of Kahneman and Tversky (1979).

An even wider catalogue of factors determining the level of cash was mentioned by Shim and Siegel (2004). As in the case of Keynes, these determinants are of an economic and behavioural character and complement each other. In practice, the separation of factors which are a result of rational economic reasons, from decisions motivated by psychological factors is extremely difficult, because of their mutual interpenetration and difficulties in quantifying behavioural factors. The identification of psychological aspects related to shaping financial liquidity and the strength of their impact is therefore an extremely valuable, desirable direction of research in the discipline of finance.

\section{BEHAVIOURAL FINANCES IN AGRIBUSINESS -A REVIEW OF RESEARCH}

Research in the field of behavioural finance in agriculture is a very interesting and prospective research area. It can be applied to the issues of taxation in agriculture, investment, financial planning, the as- sessment of state intervention effectiveness, capital structure and the identification of causes of payment bottlenecks (Zaleśkiewicz, 2012). Studies that take into account psychological factors, as the authors themselves note, are frequently of an initial character and can not be generalized to the population of farms and enterprises in the food processing sector. These studies are largely based on an economic experiment whose research sample consists of students trying to make decisions in conditions of incomplete information, taking into account their individual psychological characteristics (Kropp et al., 2009).

Among world-wide studies that take into account psychological factors in financial management, research by Kropp et al. (2009) deserve special attention. The authors used an economic experiment to establish the relationship between wealth and creditworthiness. Researchers proved that creditworthiness results more from a relative, arbitrary perception of wealth and social position than from an economic calculation that is an image of the individual's actual wealth. Numerous studies and analyses in the field of broadly understood finances (excluding agricultural finances), including behavioural factors, were also implemented by Zielonka (2005), Szyszko (2009), Mastalerz (2010) and Swacha-Lech (2012).

Research that includes psychological factors is being more frequently implemented in relation to agriculture. The first studies at the interface between classical finances and behavioural finance were Phimister's (1995) analyses regarding the impact of loan restrictions on agricultural holdings. The author has proved that the loan restrictions among Danish dairy farms are not determined by the size of the farm, but by the share of agricultural land owned by the farm. Thus, the experiment indicated, similarly to Kropp and others, a subjective perception of wealth.

Research by Musshoff and Hirschauer (2011) indicated that limited rationality among farmers is a significant determinant of their approach, in particular among farmers unwilling to change. These studies constituted a case study aimed at establishing a financial decision making mechanism by farmer-borrowers and by means of an analysis taking into account incomplete information and limited cognitive abilities. 
The studies of Tubetov, Maart-Noelck and Musshoff (2013) included an experimental approach to compare farmers' investment behaviour and determine whether they are convergent with financial factors, i.e. NPV benchmarks and real options. Research has shown that farmers have a greater preference for maintaining liquid means allowing them to maintain a high degree of flexibility - by giving up viable investment projects. The investment processes and attitudes of farmers towards investments were also the subject of research by Ihli, Maart-Noelck and Musshoff (2013). The researchers proved that farmers benefit from learning and waiting for investment, and social and demographic factors (as well as economic factors) affected investment behaviour.

Behavioural finance in relation to agriculture is also an increasingly popular topic in Poland, although the number of studies in this field can certainly be considered unsatisfactory. The most important analyses include research by Gomez y Paloma et al. (2008), who drew attention to the diversification of farmers' investment plans - which, according to researchers, are determined more by the individual psychological characteristics of the farmer and farm resources than by the farm management system and the direction of production. The subject of behavioural finance with regard to the finances of agriculture and its surroundings was also undertaken by FrancDąbrowska (2010). The author presented theoretical considerations regarding the role of profit in light of various economic trends, also in the perspective of the behavioural theory of the enterprise. Behavioural finance in relation to the agricultural environment was also the subject of research by Siudek (2011). The author proposed a theoretical behavioural model that takes into account the maximization of benefits of cooperative bank members from transactions concluded with them (also by farmers).

Kata's research (2013) carried out on a random sample of farmers in Poland proved, on the basis of statistical analysis, that behavioural factors, such as risk-based attitude, openness to cooperation and satisfaction with life status, together with demographic characteristics, have a significant impact on farmers' decisions in the credit market.

\section{CONCLUSIONS}

The economic argument concerning the evolution of the homo oeconomicus concept points to the shortcomings of mainstream economics. The decision maker's model and decision-making conditions adopted by it should therefore be treated as a certain simplification, which enables the estimation of strictly economic values. The assumption pointing to the full rationality of decision-makers, unlimited view, egoism and opportunism seems to be insufficient and to a large extent deviating from reality. As a result, economics becomes a theoretical science, increasing the distance in relation to economic practice.

This does not imply, however, the need to replace the previous achievements of economics with behavioural finance. The author postulates a broader inclusion of elements of psychology and psychoanalysis into classical economic views. A fundamental doubt may be raised by the fact that elements of behavioural finance, which are obvious and brought to our awareness by most researchers, are not present in previous theories and economic views. In the author's opinion, only the current level of economic modernization, concentration on nuances and details, growing number of information sent to decision-makers and the related increase of information asymmetry mean that the 21 st century has brought with it a clear need to supplement (and sometimes correct) classical economic views with issues concerning imperfect decision-making conditions, as well as imperfections of decision-makers themselves and different priorities. Before that, however, it is justifiable to develop and consolidate the achievements of behavioural finance at a conceptual and methodological level. Only the inclusion of elements of behavioural finance in the classical economy will allow for adapting the mainstream economics to an extremely dynamic reality.

As Rinaldi (2009) observes, there is now a need to replace the commonly criticized, negated, and yet still functioning mainstream concept of homo oeconomicus with a different, alternative concept taking into account elements of psychology and psychoanalysis. The desired direction of further research is, therefore, oriented towards the development of the concept of 
neuro oeconomicus - an economic human, taking into account certain shortcomings resulting from our capabilities and imperfections which are of a cognitive and motivational nature.

\section{REFERENCES}

1. Arystoteles (1953). Polityka (Policy). Translated by L. Piotrowicz. Zakład im. Ossolińskich, Wrocław.

2. Augier, M., Feigenbaum E. (2003). Herbert Simon - Biographical Memoirs. In: Proceedings of the American Philosophical Society, 147 (2), p. 196.

3. Becker, G.S. (1990). Ekonomiczna teoria zachowań ludzkich (The economic approach to human behavior). PWN, Warszawa, pp. 15-17, 23, 25.

4. Franc-Dąbrowska, J. (2008). Ocena płynności finansowej przedsiębiorstw rolniczych [Assessment of agricultural companies' financial liquidity]. Zagadnienia Ekonomiki Rolnej, 1 (314), pp. 43-59.

5. Franc-Dąbrowska, J. (2010). Teoretyczne i praktyczne aspekty gospodarowania zyskiem $\mathrm{w}$ przedsiębiorstwach rolniczych [Theoretical and practical aspects of profit management at agricultural enterprises]. Wydawnictwo SGGW, Warszawa.

6. Franc-Dąbrowska, J. (2011). Pułapka płynności Keynesa a dylematy oceny płynności przedsiębiorstw rolniczych [The Keynes liquidity trap and dilemma for liquidity estimation in agricultural enterprises]. Zeszyty Naukowe SGGW w Warszawie. Ekonomika i Organizacja Gospodarki Żywnościowej, 91, pp. 5-16.

7. Gomez y Paloma, S., Majewski, E., Raggi, M., Viaggi, D. (2008). Wpływ wspólnej polityki rolnej na zachowania inwestycyjne rolniczych gospodarstw domowych w Polsce [The impact of the common agricultural policy on the investment behaviour of polish farm households]. Roczniki Nauk Rolniczych, Seria G, 94 (2), pp. 94-105.

8. Hobbes, T. (1954). Lewiatan, czyli materia, forma władza państwa kościelnego i świeckiego [Leviathan; or the Matter, Form, and Power of a Commonwealth, Ecclesiastical and Civil]. Translated by C. Znamierowski. PWN, Warszawa.

9. Ihli, H.J., Maart-Noelck, S.C., Musshoff, O. (2013). Does timing matter? A real options experiment to farmers' investment and disinvestment behaviours. Australian Journal of Agricultural and Resource Economics (Early View).

10. Kahneman, D., Tversky, A. (1979). Prospect theory: An analysis of decision under risk. Econometrica, 46 (2), pp. 171-185.
11. Kata, R. (2013). Czynniki behawioralne i demograficzne wpływające na korzystanie przez rolników z kredytów inwestycyjnych [Behavioral and Demographic Factors Determining the Use of Investment Loans by Farmers]. Zeszyty Naukowe SGGW w Warszawie. Ekonomika i Organizacja Gospodarki Żywnościowej, 103, pp. 53-65.

12. Keynes, J.M. (2003). Ogólna teoria procentu, zatrudnienia i pieniądza [The General Theory of Employment, Interest and Money]. PWN, Warszawa.

13. Kropp, J., Turvey, C., Just, D., Kong, R., Pei Guo, P. (2009). Are the poor really more trustworthy? A micro-lending experiment. Agricultural Finance Review, 69 (1), pp. 67-87.

14. Leibenstein H. (1988). Poza schematem homo oeconomicus [Beyond Economic Man]. PWN, Warszawa.

15. Locke, J. (1995). Rozważania dotyczące rozumu ludzkiego [An Essay concerning human understanding]. Translated by B.J. Gawecki. PWN, Warszawa.

16. March, J.G., Simon, H.A. (1964). Teoria organizacji [Theory of Organisational Equilibrium]. PWN, Warszawa.

17. Masztalerz, M. (2010). Użyteczność sprawozdań finansowych dla inwestorów giełdowych w świetle finansów klasycznych i behawioralnych [The Usefulness of Financial Statements to Investors in the Light of Classical and Behavioral Concept of Finance]. Zeszyty Teoretyczne Rachunkowości, 57 (113), pp. 41-55.

18. Mądra, M.. (2007). Poziom generowanych przepływów pieniężnych a zadłużenie gospodarstw indywidualnych [Level of generated cash flows and indebtedness of individual farms. Strategies for the growth of the company's value]. In: Urbańczyk, E. (ed.) Strategie wzrostu wartości przedsiębiorstwa [Strategies for the growth of the company's value]. Wydawnictwo Kreos, Szczecin, pp. 271-282.

19. Mill, J.S. (1959). Utylitaryzm [Utilitarianism]. Translated by M. Ossowska, A. Kurlandzka. PWN, Warszawa.

20. Mullainathan, S., Thaler, R.H. (2000). Behavioral Economics. MIT Deptartment of Economics Working Paper 00-27.

21. Musshoff, O., Hirschauer. N. (2011). A behavioral economic analysis of bounded rationality in farm financing decisions: first empirical evidence. Agricultural Finance Review, 71 (1), pp. 62-68.

22. Phimister, E. (1995). The impact of borrowing constraints on farm households: a life-cycle approach. European Review of Agricultural Economics, 22, pp. $61-86$

23. Platon (2003). Państwo [The State]. Translated by W. Witwicki. Antyk, Kęty. 
24. Rinaldi, A. (2009). Homo economicus? Neuroeconomics and other disciplines aim to identify the biological traits governing our financial behaviour, but not without accompanying criticism. EMBO reports 10.8.

25. Shim, J.K., Siegel, J.G. (2004). Dyrektor finansowy [Financial Management] Oficyna Ekonomiczna, Warszawa.

26. Simon, H.A. (1976.) Działanie administracji. Proces podejmowania decyzji w organizacjach administracyjnych [Administrative behavior: A study of decisionmaking processes in administrative organization. PWN, Warszawa.

27. Simon, H.A. (1979). Rational Decision Making in Business Organizations, The American Economic Review, 69 (4), pp. 493-513.

28. Simon, H.A. (1997). Models of Bounded Rationality: Emprically Grounded Economic Reason. Vol. 3. MIT Press, Cambridge.

29. Siudek, T. (2011). Bankowość spółdzielcza w Polsce i wybranych krajach Unii Europejskiej - wymiar ekonomiczny, organizacyjny i społeczny [Cooperative banking in Poland and selected European Union countries - economic, organizational and social perspectives]. Wydawnictwo SGGW, Warszawa.

30. Smith, A. (1954). Badania nad naturą i przyczynami bogactwa narodów [An Inquiry into the Nature and Causes of the Wealth of Nations]. PWN, Warszawa.

31. Smith, A. (1989). Teoria uczuć moralnych [The Theory of Moral Sentiments]. PWN, Warszawa.
32. Stoner, J., Freeman, R., Gilbert, D.R. (1999). Kierowanie [Management]. PWE, Warszawa.

33. Swacha-Lech, M. (2012). Problem gromadzenia oszczędności w świetle dorobku finansów behawioralnych [Individuals' Savings Problem in the Light of Behavioural Finance Achie Vement]. Studia Ekonomiczne, Zeszyty Naukowe Wydziałowe Uniwersytetu Ekonomicznego w Katowicach, 105, pp. 73-80.

34. Szyszka, A. (2009). Behawioralne aspekty kryzysu finansowego [Behavioural aspect of the financial crisis]. Bank i Kredyt, 4.

35. Thaler, R., Sunstein C. (2012). Impuls. Jak podejmować właściwe decyzje dotyczące zdrowia, dobrobytu i szczęścia [Nudge: Improving Decisions about Health, Wealth, and Happiness]. Zysk i S-ka, Poznań.

36. Tubetov, D., Maart-Noelck, S.Ch., Musshoff, O. (2013). Real options or net present value? An experimental approach on the investment behavior of Kazakhstani and German farmers. Agricultural Finance Review, 73 (3), pp. 426-457.

37. Von Humboldt, W. (2008). The limits of state action. Cambridge University Press, Cambridge.

38. Wilkinson, N., Klaes, M. (2012). An Introduction to Behavioral Economics. Palgrave Macmillan, New York.

39. Zaleśkiewicz, T. (2012). Psychologia ekonomiczna [Economic Psychology]. PWN, Warszawa.

40. Zielonka, P. (2005). Efekt dyspozycji a teoria perspektywy [The disposition effect and prospect theory]. Decyzje, 3, pp. 55-77. 